\title{
Primary Actinomycosis of the Breast Masquerading as Malignancy: Diagnosis by Fine Needle Aspiration Cytology
}

\author{
Chinky Gupta Prem Singh Sanjay Bedi Kalyani Kapur
}

M.M. Institute of Medical Sciences and Research, Mullana, Ambala, Haryana, India

\author{
Keywords \\ Actinomycosis · Malignancy · Breast · Cytology
}

\section{Dear Editors,}

A case of actinomycosis of the breast mimicking breast cancer is presented. Although it is not uncommon for actinomycosis to simulate cancer in other locations, the mammary involvement is unusual. The case was diagnosed by fine needle aspiration cytology (FNAC) and subsequently confirmed by histopathological examination. Actinomycosis is a rare cause of granulomatous suppurative mastitis, sometimes mimicking malignancy [1].

A 32-year-old woman presented to our institute with a history of a painful breast lump of 20 days duration. She was married, with a 2-year-old living male child. There was no history of fever, nipple discharge, breast trauma, orodental lesions, or respiratory problems. She was not diabetic and did not receive any immunosuppressive therapy. Local examination revealed a tender, firm to hard, partially fixed mass, measuring $7 \times 8 \mathrm{~cm}$, in the upper outer quadrant of the right breast. The overlying skin was hyperemic and edematous with no discharging sinuses. The contralateral breast and axillary lymph nodes were unremarkable. The oral cavity appeared normal. Hematological and biochemical parameters as well as chest X-rays were normal. FNAC of the right breast lump was performed.

FNAC smears showed mixed inflammatory cells consisting of predominantly neutrophils, lymphocytes admixed with epithelioid cells, plasma cells, and giant cells in a necrotic background. Amidst the inflammatory cells, typical colonies of branching filamentous and beaded bacteria giving a 'bales of wool' appearance reminiscent of actinomycosis were seen (fig. 1). These were gram-positive and acid fast-negative. Cytology for malignant cells was negative. To confirm the diagnosis and exclude any possibility of malignancy, the lump was excised. Histopathological examination revealed suppurative and granulomatous inflammation with formation of micro-abscesses containing grains of Actinomyces israelii giving the cotton ball appearance; this was later confirmed by Grocott's methamine silver stain (fig. 2). The patient recovered after antibiotic treatment, and ultrasonographic followup was normal.

First described by Ammentrop in 1893, primary actinomycosis of the breast is very rare and most commonly caused by $A$. israelii which normally inhabits the mouth, colon, and vagina [2, 3]. Primary forms directly affect the breast but the etiology is unknown; possible causes include infection of the lactiferous ducts due to trauma during breast feeding or kissing. In secondary actinomycosis, extension of the primary infection is seen which could be through the thoracic cage, extending from the ribs, to the muscles, and finally the breast [4].

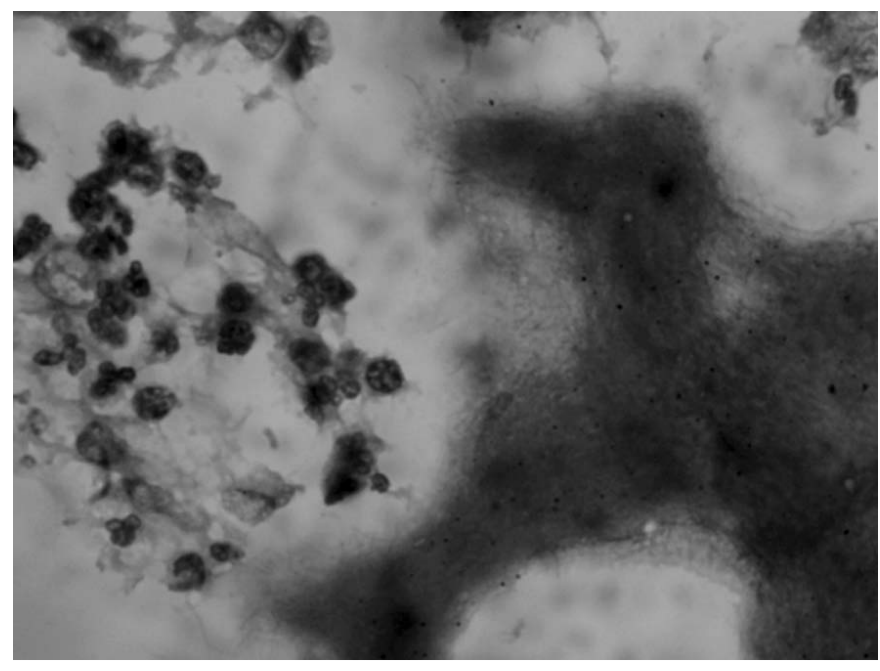

Fig. 1. Actinomycosis. Fine needle aspiration cytology smear showing intertwined branching filaments giving a 'bales of wool' appearance against the background of inflammatory cells (May-Grünwald-Giemsa, ×400).

\begin{tabular}{ll}
\hline KARGER & $\begin{array}{l}\text { ( ) 2012 S. Karger GmbH, Freiburg } \\
1661-3791 / 12 / 0072-0153 \$ 38.00 / 0\end{array}$ \\
$\begin{array}{l}\text { Fax +49 761 452 0714 } \\
\text { Information@Karger.de } \\
\text { www.karger.com }\end{array}$ & $\begin{array}{l}\text { Accessible online at: } \\
\text { www.karger.com/brc }\end{array}$
\end{tabular}




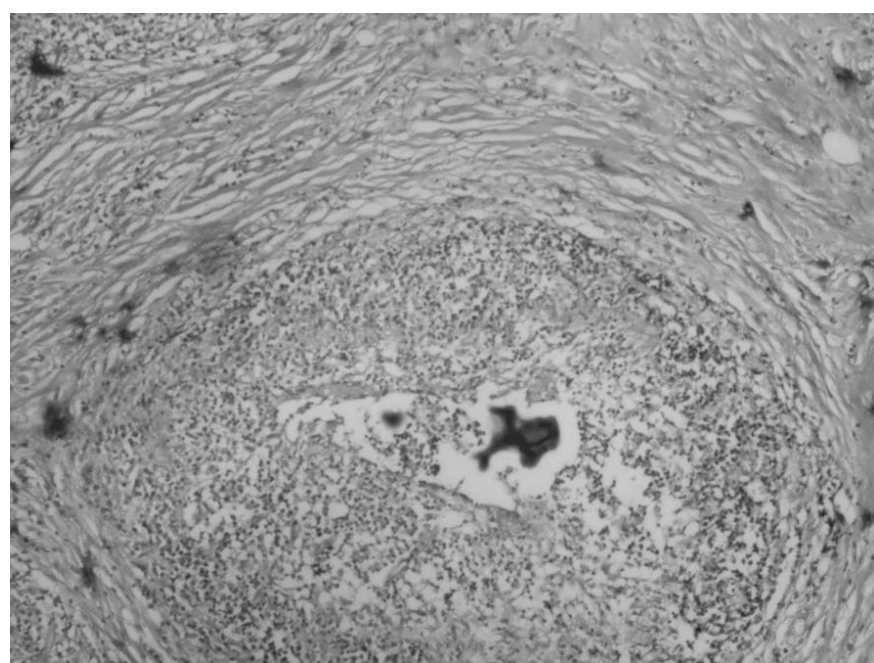

Fig. 2. Histological section showing actinomycosis colonies in the centre of the abscess cavity (Grocott's Methamine Silver, $\times 100$ ).
Usually presenting as recurrent abscesses with or without fistulas, the presentation of actinomycosis as a breast mass is unusual, rare, and difficult to differentiate from inflammatory carcinoma [2]. The pivotal role of FNAC in the diagnosis of actinomycosis presenting as a painful breast lump can not be emphasized enough. Being a non-traumatic and accurate diagnostic procedure, a diagnosis can be reached at an early stage and unnecessary major surgery can be avoided. Cytological diagnosis is a quick, easy, and cost-effective outpatient procedure which is easily acceptable for the patients [5]. Our case report suggests that primary actinomycosis can be reliably diagnosed by FNAC, and malignancy can be excluded.

\section{Disclosure Statement}

The authors declare no conflict of interests.

\section{References}

1 Daie Ghzvini R, Zibafar F, Omidi K: First case report of primary actinomycosis of the breast due to Actiomyces israelii from Iran. Acta Med Iran 2003;41:110-112.

2 Salmasi A, Asgari M, Khodadadi, Rezaee A: Primary actinomycosis of the breast presenting as a breast mass. Breast care (Basel) 2010;5:105-107.
3 Attar KH, Waghorn D, Lyons M, Cunnick G: Rare species of actinomyces as causative pathogen in breast abscess. Breast J 2007;13:501-505.

4 De Barros N, Issa FK, Barros AC, D'Avila MS, Nisida AC, Chammas MC, Pinoti JA, Cerri GG: Imaging of primary actinomycosis of the breast. AJR Am J Roentgenol 2000;174:1784-1786.
5 Hemalata M, Prasad S, Venkatesh K, Niveditha SR, Kumar SA: Cytological diagnosis of actinomycosis and eumycetoma: a report of two cases. Diagn Cytopathol 2010;38:918-920. 